\title{
KRATICE U TEKSTOVIMA
}

(prema Literaturi)

ARJ = Rječnik hrvatskoga ili srpskoga jezika I-XXIII, 1880-1976

BG = Bauer, J., Grepl, M., 1970

BMŽ = Bauer, J. Mrázek, R., Žaža, S., 1960

$\mathrm{BRS}=$ Belaruska-ruski sloünik 1962

$\mathrm{BTR}=$ Bălgarski tălkoven rečnik 2004

ČBR $=$ Čukalov 1960

ČES = Rejzek, J., 2001

ČL = Filipec, J., Čermák, F., 1985

ČNK2000 = Český národní korpus - SYN2000 (2005)

ČNK2005 = Český národní korpus - SYN2005 (2005)

ČNK2006 = Český národní korpus - SYN2006pub (2005)

$\check{\mathrm{C}} \mathrm{RB}=\check{\mathrm{Cuk}}$ alov 1972

EJP = Encyklopedia wiedzy o języku polskim, 1978

FRHSJ = Matešić, J., 1982

$\mathrm{GM}=$ Monastyrec'ka 2007

GRJ $=$ Grammatika russkogo jazyka 1980

GSRLJ = Grammatika sovremennogo russkogo literaturnogo jazyka 1970

HFR = Menac, A., Fink-Arsovski, Ž., Venturin, R., 2003

HG = Barić, E., Lončarić, M., Malić, D. ... 1995

HNK = Hrvatski nacionalni korpus $-H N K \_v 20$. (2005)

HSRPF = Fink-Arsovski, Ž. et al., 2005

$\mathrm{JS}=$ Jezični savjetnik s gramatikom, 1971

KTM = Koseska Toszewa, V., Mindak, J., 1984

L = Labocha, J., 1995

OER = Osmojezični enciklopedijski rječnik, 1987

$\mathrm{P}=$ Pisarkowa, K., 1972

PČP = Pravidla českého pravopisu, 1998

PF = Fink-Arsovski, Ž., 2002

PRŠ = Pauliny, E., Ružička, J., Štolc, J., 1968

PS = Pivtorak, Skopnenko 2006

PSFJP = Bąba, S., Dziamska, G., Liberek, J., 1995

$\mathrm{PSP}=$ Pravidlá slovenského pravopisu, 1991

$\mathrm{RBK}=$ Fouilloux, D. et al., 1999

RMJ = Rečnik na makedonskiot jazik 1961-1966

RS = Chevalier, J., Gheerbrant, A., 1987

RSBJ = Rečnik na săvremennija bălgarski knižoven ezik 1955-1959

SČFI = Čermák, F., Hronek, J., Machač, J., 1983

SČRF = Stěpanova, L., 2004

SJP = Słownik języka polskiego, 1978-1981 
SSJ = Slovník slovenského jazyka, 1959-1968

SUM = Slovnyk ukrajinskoji movy 1970-1978

$\mathrm{Sz}=$ Szober, S., 1962

$\breve{S}=$ Śmilauer, V., 1966

$\mathrm{T}=$ Toporišǐč, J., 1982; Toporišič, J., 1984

$\mathrm{V}=$ Valgina 1978

VTTH = Veatch, Thomas C., 1998

ZLČ = Zaorálek, J., 1963 